\title{
FRUIT OF THE POISONOUS TREE-A PLEA FOR RELEVANT CRITERIA
}

In 1914, the United States Supreme Court, in an endeavor to protect the rights guaranteed by the fourth amendment, adopted the exclusionary rule in the case of Weeks $v$. United States. ${ }^{1}$ Almost fifty years later, after considerable experimentation among the courts ${ }^{2}$ and debate among the commentators, ${ }^{3}$ the Court, in Mapp v. Ohio, ${ }^{4}$ incorporated the exclusionary rule into the due process requirements of the fourteenth amendment.

The purpose of the exclusionary rule is to deter unlawful police practices by depriving law enforcement officials of any benefit derived from such practices. ${ }^{5}$ The hope is that removal of the incentive to engage in such practices will cause the practices themselves to disappear. $^{b}$ Of course, the deterrence would be greatest if complete immunity from prosecution were granted in cases where unlawful police

1232 U.S. 383 (1914). Private letters of the defendant were illegally seized by federal officers and were admitted in evidence against him in a subsequent federal prosecution. On appeal from the defendant's conviction, the Court concluded that if the protections of the fourth amendment were to be meaningful, evidence seized in violation of them must be inadmissible in prosecutions against the defendant. Id. at 393.

2 See, e.g., Wolf v. Colorado, 338 U.S. 25 (1949) (state courts free to adopt or not to adopt the exclusionary rule), overruled by Mapp v. Ohio, 367 U.S. 643 (1961); Weeks v. United States, 232 U.S. 383 (1914) (evidence obtained by state officials and given to federal officials was admissible despite state official's violation of fourth amendment right-the "silver platter" doctrine), overruled by Elkins v. United States, 364 U.S. 206 (1960).

3 See, e.g., pro exclusionary rule: Allen, The Wolf Case; Search and Seizure, Federalisin, and the Civil Liberties, 45 ILL. L. REv. 1 (1950); Atkinson, Admissibility of Evidence Obtained Through Unreasonable Searches and Seizures, 25 CoLUM. L. REv. 11 (1925) ; Beise1, Control Over Illegal Enforcement of the Criminal Law: Role of the Supreme Court, 34 B.U.L. REv. 413 (1954); Frankel, Searches and Seizures During the Truman Era, 25 So. CAL. L. Rev. 1 (1951); Paulsen, The Fourteenth Amendment and the Third Degree, 6 Stan. L. Rev. 411 (1954).

Con exclusionary rule: Grant, Circumventing the Fonth Amendment, 14 So. CaL. L. REv. 359 (1941) ; Harno, Evidence Obtained by Illegal Search and Seizure, 19 InL. L. Rev. 303 (1925); Plumb, Illegal Enforcement of the Law, 24 CoRnell L.Q. 337, 354-85 (1939) ; Comment, Police Regulation by Rules of Evidence, 42 Mrсн.

L. REV. 679 (1944).

4367 U.S. 643, 655 (1961).

5 See Machen, The Law of Search and Seizure 10 (1950); Maguire, EviDENCE of GUILT 215 (1959); MCCoRMICK, EVIDENCE 291 (1954); Amsterdam, Search Seizure, and Section 2255: A Comment, 112 U. PA. L. Rev. 378, 388-89 (1964); Barrett, Exchusion of Evidence Obtained by Illegal Searches-A Comment on People vs. Cahan, 43 CALIF. L. REv. 565, 579 (1955) ; Maguire, How to Unpoison the Fruit The Fourth Amendinent and the Exchusionary Rule, 55 J. CRIM. L., C. \& P.S. 307 (1964); Traynor, Mapp v. Ohio at Large in the Fifty States, 1962 Dure L.J. 319, $334-35$

6 Granted that the adoption of the exclusionary rule will not prevent all illegal searches and seizures, it will discourage them. Police officers and prosecuting officials are primarily interested in convicting criminals. Given the exclusionary rule and a choice between securing evidence by legal rather than illegal means, officers will be compelled to obey the law themselves since not to do so will jeopardize their objectives.

People v. Cahan, 44 Cal. 2d 434, 448, 282 P.2d 905, 913 (1955) (Traynor, J.). 
conduct has occurred, ${ }^{7}$ or if an affirmative method of punishing the police were employed. However, use of the exclusionary rule as a means of controlling police practices is not without social cost. Regardless of the amount of unlawful police conduct which takes place, it is generally only those cases in which the unlawful conduct discloses strong evidence of guilt which reach the courts. Consequently, application of the doctrine of exclusion in any particular case usually means the release of a guilty individual. ${ }^{8}$ This result is wholly undesirable and should be minimized whenever possible. ${ }^{9}$ Exclusion is not intended to redress a wrong to the defendant by releasing him, but is designed only to curb undesirable police conduct. ${ }^{10}$ Therefore, complete immunity goes too far.

This conflict of social interests makes every motion for exclusion an occasion which places the court on the horns of a dilemma. It must choose between the lesser of two evils: holding the evidence inadmissible and permitting a guilty person to go unpunished; holding the evidence admissible and condoning and possibly even encouraging unconstitutional police conduct. ${ }^{11}$

Nonetheless, as to evidence obtained directly through unconstitutional police practices, the Supreme Court has conclusively made the choice. In Silverthorne Lumber Co. v. United States, ${ }^{12}$ government officials illegally seized corporate books and documents of the defendant. Under authority of the Weeks decision, the defendant obtained a court order and secured return of the seized documents. However, while in possession of the seized goods, government officials had photographed them and used the photographs to obtain a subpoena requiring the defendant to produce the originals at trial. The defendant refused to comply with the subpoena and was cited for contempt. On appeal the Supreme Court held that the government could not use the photographs to support a subpoena and reversed the contempt conviction saying: "The essence of a provision forbidding the acquisition of evidence in a certain way is that not merely evidence so acquired shall not be used before the court, but that it shall not be used at all." 13

This decision is generally credited with fathering the doctrine of "taint" ${ }^{14}$ or "fruit of the poisonous tree" as it was later christened. ${ }^{15}$

7 See the rather exhaustive footnote appearing in Broeder, Wong Sun v. United States: A Study in Faith and Hope, 42 NeB. L. Rev. 483, 516 n.121.

8 Amsterdam, supra note 5 , at 389 \& n.51.

Id. at 388-89.

10 See Note, 114 U. PA. L. Rev. 570,574 (1966).

11 See 8 Wigmore, Evidence \$2183 (1940); Comment, Police Regulation by Rules of Evidence, 42 Mich. L. Rev. 679, 685 (1944).

12251 U.S. 385 (1920).

13 Id. at 392.

14.Cf. Note, 114 U. PA. L. Rev. 570, 572 n.16 (1966).

15 Nardone v. United States, 308 U.S. 338, 341 (1939). 
This doctrine is merely a facet of the exclusionary rule. ${ }^{16}$ Essentially, it is a response to the realization that if police officers are permitted to use knowledge gained from unlawfully obtained evidence to obtain the same or other valuable evidence legally, an inducement to commit such unlawful practices continues to exist. ${ }^{17}$

Ideally, exclusion should be utilized only to the point where the increased benefit accruing to society from the additional deterrent against unlawful police practices equals the detriment incurred by society due to the release of criminals. ${ }^{18}$ Unfortunately, the amount of knowledge necessary to find this point of equilibrium appears to be, in light of what is known about the way deterrence operates, more "than now seems knowable." 19

The Supreme Court has spoken to the issue in only three major decisions. In Silverthorne, after stating that evidence gained by illegal practices could not be used at all, Mr. Justice Holmes was quick to qualify his words:

Of course this does not mean that facts thus [illegally] obtained become sacred and inaccessible. If knowledge of them is gained from an independent source they may be proved like any others, but the knowledge gained by the Government's own wrong cannot be used by it in the way proposed. ${ }^{20}$

This qualification represents a policy decision that the need for deterrence does not extend so far as to require affirmative punishment by making facts unlawfully discovered forever unusable. All that is deemed necessary is that police officers be deprived of any benefit from their unlawful conduct. If the government can show that it obtained the challenged evidence by lawful means and from a source completely independent of the illegality, the policy is satisfied. An awareness by police that only information obtained in the proper manner will be useable, should be sufficient to deter unlawful conduct.

Twenty years later the Supreme Court again spoke to the issue. In Nardone $v$. United States, ${ }^{21}$ a wiretapping case, ${ }^{22}$ the issue was

16 See Note, 114 U. PA. L. Rev. 570, 572 (1966).

17 For purposes of this Comment, a distinction is not drawn between unlawful police conduct which rises to the level of a constitutional violation and that which does not. The purpose of a "taint" rule is to support the exclusionary rule. Once it has been determined that exclusion is required, the doctrine of "taint" should be applicable without regard to whether the exclusion is required by the Constitution or by rules of law promulgated by courts or legislatures. See notes $22,47,53,95$ infra.

18 Professor Amsterdam has called this "the point of diminishing returns of the deterrence principle." Amsterdam, supra note 5, at 390. See also Barrett, suspra note 5, at 583; Note, 8 U.C.L.A.L. Rev. 454, 457 (1961) ; Note, 28 U. CEI. L. REv. 664,666 (1961).

19 Amsterdam, supra note 5 , at 390 .

20251 U.S. at 392 (1920).

21308 U.S. 338 (1939).

22 For purposes of this Comment wiretapping cases treated as equivalent to unconstitutional search and seizure cases. See note 17 sipra. See MAgure, Evidence of 
whether the defendant was entitled to inquire of the prosecution concerning the use to which it had put illegally obtained evidence. Deciding in favor of the defendant, Mr. Justice Frankfurter, writing for the Court, reaffirmed the "independent source" doctrine of Silverthorne, ${ }^{23}$ coined the phrase "fruit of the poisonous tree" ${ }^{24}$ and went on to establish the doctrine of attenuation.

Sophisticated argument may prove a causal connection between information obtained through illicit wire-tapping and the Government's proof. As a matter of good sense, however, such connection may have become so attenuated as to dissipate the taint. ${ }^{25}$

This decision was the first to authoritatively recognize that even where the challenged evidence did not have an "independent source," it was possible for it to be admissible.

Twenty-three years after the Nardone decision, the high court again dealt with the problem of the scope of "taint." In Wong Sun $v$. United States, ${ }^{26}$ federal narcotics agents unlawfully entered defendant's home at 6:00 a.m. and arrested him. In the course of making several statements which were inadmissible against him, the defendant told the agents the identity and location of a third party. The agents immediately went to the third party and in due course recovered narcotics from him which were introduced at trial against the defendant. Holding that the narcotics were inadmissible as "fruit," the Court articulated the following standard:

We need not hold that all evidence is "fruit of the poisonous tree" simply because it would not have come to light but for the illegal actions of the police. Rather, the more apt question in such a case is "whether, granting establishment of the primary illegality the evidence to which instant objection is made has been come at by the exploitation of that illegality or instead by means sufficiently distinguishable to be purged of the primary taint." 27

GuIIT 220 n.8 (1959) ; Maguire, How to Unpoison the Fruit-The Fourth Amendment and the Exchwionary Rule, 55 J. CRIM. L., C. \& P.S. 307,309 n.8 (1964). But see, Broeder, supra note 7, at 542 n.193.

23308 U.S. at $340-41$.

$24 I d$. at 341 .

25 Ibid. (Emphasis added.)

26371 U.S. 471 (1963). For an analysis of the aspect of Wong Sun dealing with statements following an illegal arrest, see Kamisar, Illegal Searches or Seizures and Contemporaneous Incriminating Statements: $A$ Dialogue on a Neglected Area of Criminal Procedure, 1961 ILL. L.F. 78.

27 Id. at 478-88. (Emphasis added.) 
Silverthorne, Nardone and Wong Sun thus establish the three major standards by which the lines of exclusion generally are said to be drawn. ${ }^{28}$

Professor Anthony G. Amsterdam has suggested that since the information necessary to locate the point of diminishing returns of the exclusionary rule is unavailable, the goal of providing a deterrent to unlawful police conduct while minimizing the number of guilty criminals who must be released unpunished might well be accomplished by flipping a coin and allowing fifty per cent of objecting defendants to challenge the admission of excludible evidence, while requiring the other fifty per cent to stand trial without the benefits of exclusion. ${ }^{29}$ $\mathrm{He}$ points out, of course, that no such practice could ever exist. "[T] hat is not the way in which a court may operate; it appears intolerably arbitrary and would furnish cause for dangerous resentment by the criminal accused." $30 \mathrm{He}$ maintains, however, that the doctrines of "standing" and "attentuation" which presently govern the determination of what "tainted" evidence must be excluded are nothing more than judicial contrivances designed "to serve the flipped coin's purpose without the flipped coin's manifest caprice." 31

At least with respect to the federal "standing" rules, this would appear to be so. At present the "standing" doctrine requires that the defendant have some sort of proprietary interest in the unlawfully obtained evidence, ${ }^{32}$ or that he at least have been legitimately on the violated premises ${ }^{33}$ to be entitled to object to the admission of any such evidence. The rationalization for these standing requirements is that since the exclusionary rule was originally premised on both the fourth and the fifth amendments, the right to invoke the rule should be limited, like the right to invoke the personal protections of

28 There are others closely derived from these. See, e.g., Lawn v. United States, 355 U.S. 339, 355 (1958) (evidence was not "derived from"); United States v. Sansone, 231 F.2d 887, 891 (2d Cir. 1956) ("fruit of"); United States v. Coplon, 185 F.2d 629, 636 (2d Cir. 1950) (unlawfully obtained information "has not 'led,' directly or indirectly to the discovery" of the proffered evidence). See also Fahy v. Connecticut, 375 U.S. 85 (1963), holding that a confession induced by confronting the accused with illegally seized evidence is inadmissible.

29 Amsterdam, supra note 5, at 390 .

30 Ibid.

31 Ibid.

32 See, e.g., Murray v. United States, 333 F.2d 409 (10th Cir.), cert. granted, 380 U.S. 527 (1964), judgment vacated, 351 F.2d 330 (10th Cir. 1965), cert. denied, 383 U.S. 949 (1966); Williams v. United States, 323 F.2d 90 (10th Cir. 1963), cert. denied, 376 U.S. 906 (1964); United States v. McDaniel, 154 F. Supp. 1 (D.D.C. 1957), aff'd per curiam, 255 F.2d 896 (D.C. Cir.), cert. denied, 358 U.S. 853 (1958); United States v. Lester, 21 F.R.D. 376 (W.D. Pa. 1957), and authorities cited therein. See also Wong Sun v. United States, 371 U.S. 471 (1963) (holding Wong Sun unable to challenge admissibility of narcotics obtained by virtue of an illegal search against Blackie Toy because Wong Sun was not a party aggrived). It is interesting to note that the Wong Sun decision is the first time the Supreme Court has ever held that a defendant lacked standing to challenge an illegal search. Broeder, supra note 7 , at 540 .

33 Jones v. United States, 362 U.S. 257 (1960). 
the fifth amendment's privilege against self-incrimination, to the party aggrieved. ${ }^{34}$ However, since the purpose of the exclusionary rule is to deter police practices, ${ }^{35}$ there is no reason why the effectiveness of the rule must be diluted by a requirement that the asserter be an aggrieved individual, or by tying the rule to a limitation peculiar to the privilege against self-incrimination. ${ }^{36}$

The illogic of the "standing" requirement is highlighted by the fact that it may well serve to defeat the purpose for which the exclusionary rule exists, and encourage rather than discourage unlawful police conduct. Once the police are certain that only an aggrieved individual can challenge the admissibility of unlawfully obtained evidence, they are free, if so inclined, to ransack, coerce and illegally seize evidence and information from all but the intended defendant, ${ }^{37}$ knowing full well that they need not fear successful challenge to the admissibility of the evidence obtained. A particularly offensive aspect of this result is that the victims of these unlawful invasions will often be innocent individuals whose only connection with the crime involved is their proximity to or association with the intended defendant. ${ }^{38}$

An additional factor indicating the irrationality of the "standing" requirement is the often unjust and undesirable results which are obtained by its application. The classic example occurs in the large conspiracy case where the owner of the seized or violated property, usually the master conspirator, goes free while his lesser conspirators are incarcerated because he, not they, owned the seized property or violated premises. ${ }^{39}$ This result can be explained only as a compromise, through which the leader must go free in the interest of deterring unlawful police conduct. At the same time, society continues to prefer to incarcerate the underlings rather than, for the sake of consistency, free all the conspirators without punishment. Such an approach strongly indicates that, at least with respect to federal "standing" requirements, Professor Amsterdam is correct when he characterizes them as nothing more than a judicially contrived substitute for coin flipping, designed to limit the number of criminals released unpunished because of the exclusionary rule.

34 See Broeder, supra note 7, at 540; Note, Judicial Control of Illegal Search and Seizure, 58 Yale L.J. 144, 156 (1948). See also FEd. R. CRIM. P. 41 (e).

35 See Traynor, supra note 5 , at 334.

36 See Broeder, supra note 7, at 540; Traynor, supra note 7, at 335; Note, supra note 34 , at 156 .

37 See National Consmission on Law Observance and Enforcenent, Report CN LAWLESSNESS IN LAw ENFORCEMENT 156 (1931); cf. Note, supra note 34, at 158.

38 Official statements from different parts of the country and our field investigation confirm that these illegal practices are sometimes employed to get information about an offense from persons who are not suspected of committing it but only of knowing about it.

Natronal Cominission on LaW OBSERvance aNd Enforcenrent, supra note 37, at 151 .

39 See Broeder, supra note 7, at 541; Note, supra note 34, at 157. 
The same can, to a certain extent, be said for some of the lines drawn by the courts to define the doctrine of "attentuation." The lower federal courts have been reluctant to abide by the rule laid down in Silverthorne that before evidence may be used by the prosecution it must be shown to have an origin independent of the primary illegality. ${ }^{40}$ The illogical exceptions which the courts have fashioned in circumventing the "independent source" rule ${ }^{41}$ offer additional support for Professor Amsterdam's conclusion.

Implicit in the "independent source" exception to the "fruits" doctrine is a policy that police not be affirmatively punished for their unlawful enforcement practices, but only prohibited from receiving any benefit from such practices. In what seems an obvious effort to limit the number of criminals released by the exclusion requirement, many courts appear to have reasoned that, where the illegally seized evidence would have been obtained by the police absent the illegality, the police have, in fact, received no benefit from their illegal conduct and the evidence need not be excluded. ${ }^{42}$

In Harlow v. United States, ${ }^{43}$ the defendant was convicted of bribery and conspiracy. On appeal, one issue was the admissibility of the products of a search warrant which was allegedly "tainted." The defendant was a government purchasing agent for European-based" "post exchanges." $\mathrm{He}$ and others were involved in a widespread conspiracy to solicit bribes. During the course of an investigation certain incriminating letters written by the defendant to a co-defendant were illegally seized. From these letters government agents were led to a co-conspirator who, upon interrogation, confessed and persuaded a second co-conspirator to confess. These two confessions were used to secure the challenged search warrant. Despite the connection between the search warrant and the primary illegality, the court held that the evidence need not be suppressed. Prior to the illegal search, a Swiss banker had reported to American officials that the first coconspirator had been making large monthly deposits of cash in his bank. The court reasoned that, suspecting the existence of a bribery scheme and knowing that the first co-conspirator was involved with the purchasing agent, the above information would naturally have led the investigating agents to interrogate the first co-conspirator. ${ }^{44}$ The court concluded that, since it could not be shown that the coconspirator would not have confessed under these circumstances, they could not declare the warrant a product of the illegal seizure of the letters. ${ }^{45}$

40 See Note, 114 U. PA. L. REv. 570, $572-73$ (1966).

41 See id. at 573 . Exclusionary Rule, 55 J. Crim. L., C. \& P.S. 307, 313-17 (1964).

${ }_{43} 301$ F.2d 361 (5th Cir.), cert. denied, 371 U.S. 814 (1962).

$44 I d$. at 373 .

45 Ibid. 
In Wayne $v$. United States, ${ }^{46}$ the police received a call from a woman informing them that the sister of a friend, the victim of an abortion, was at the defendant's apartment. The police immediately went to the defendant's apartment and allegedly ${ }^{47}$ entered unlawfully. There they found the defendant, his lawyer and a deceased woman. Rejecting a challenge to the testimony of the coroner and the receipt of an autopsy report as being. "fruit" of the unlawful entry, the court reasoned:

It was inevitable that, even had the police not entered appellant's apartment at the time and in the manner they did, the coroner would sooner or later have been advised by the police of the information reported by the sister, would have obtained the body, and would have conducted the post mortem examination prescribed by law. Thus, the necessary causal relation between the illegal activity and the evidence sought to be excluded is lacking in this case. ${ }^{48}$

Both of the above cases have taken the rule that prosecution evidence must have an independent origin and converted it to read that where the defendant cannot show that the police officers would not have discovered the challenged evidence "but for" the illegal police conduct the evidence need not be excluded. ${ }^{49}$ Such a rule is completely at odds with the purposes of the exclusionary rule. ${ }^{50}$ If the police will only be deprived of that evidence which the defendant can show they would not have been able to obtain had they not engaged in the illegality, they will in no way be deterred from such conduct; all they will stand to lose is what they would not have otherwise had and they might gain some advantage if something slips by. Moreover, the illegal route is often faster and easier than the legally required route.

In United States $v$. Sheba Bracelets, Inc. ${ }^{51}$ the defendant was convicted of making false statements in connection with the purchase of gold for jewelry manufacture. On appeal the issue was the ad-

40318 F.2d 205 (D.C. Cir. 1963), cert. denied, 375 U.S. 860 (1963).

47 The issue of the constitutionality of the search was not reached by the court. Defendant did not claim that the police violated the fourth amendment, but rather that they had violated the "announcement rule" of Miller v. United States, 357 U.S. 301 (1958). The difference is not considered significant for the purposes of this Comment. See note 17 supra. See Broeder, supra note 7, at 511 n.107 (1964), suggesting that the entry was constitutional.

48318 F.2d at 209.

49 But see Maguire, supra note 42, at 315-17.

$50 \mathrm{Cf}$. Broeder, supra note 7 , at $548 \mathrm{n} .217$. The rule is also contrary to the usually accepted rule of burden of proof in such cases.

The burden rested upon the appellant to establish [the primary illegality]

.... and that there was a reasonable possibility ... [that such illegality] tainted ... [the challenged evidence]. The burden would then pass to the government to convince the trial court that the evidence was free of taint Gilbert v. United States, 366 F.2d 923, 958 (9th Cir. 1966) (Browning, J., dissenting). 51248 F.2d 134 (2d Cir.), cert. denied, 355 U.S. 904 (1957). 
missibility of evidence obtained by Treasury agents during an allegedly unlawful search. The court held the evidence admissible on the ground that the same evidence had been supplied later to the Treasury officials by internal revenue agents who were investigating the defendant's tax returns. Although the passing of such information was illegal, the court reasoned that since the defendant failed to make a timely objection to the use by the Treasury agents of information gained by this unlawful transfer, any knowledge so gained became knowledge derived from a legitimate "independent source" and, consequently, it was irrelevant whether the information was also gained by an unlawful search by the Treasury agents. ${ }^{52}$ While it is difficult to sympathize with a criminal who is justly punished, it is equally difficult to condone the result reached by the court. Here, it used evidence obtained from one illegality to "untaint" evidence obtained from another illegality and, in effect decided that two wrongs do make a right.

Still another example of artificial line-drawing may be found in Killough v. United States. ${ }^{53}$ There, the defendant murdered his wife and buried her body. In the process of making an inadmissible confession ${ }^{54}$ the defendant revealed the location of his wife's body which, when found, was already two-thirds decomposed and almost unrecognizable. At trial the defendant moved to suppress the autopsy report and the coroner's testimony concerning his wife's body. Despite the fact that knowledge of the body and, consequently, the coroner's testimony were derived from the defendant's confession, the court sustained the admissibility of the challenged evidence. The court reasoned:

It is clear that the evidence of the Coroner and his assistants in no way connected Killough with the body. . . . The mere fact that the body was discovered. . . because of Killough's disclosure of its whereabouts in his illegally secured confessions is not determinative. We cannot conclude here . . . that the body would not have been discovered "but for" Killough's confession . . . .55

The fact that within the technical rules of evidence, the mere existence of the body and the manner in which the victim died "in no way connected" the defendant with the body seems irrelevant. Dis-

52 Id. at 141 .

53 336 F.2d 929 (D.C. Cir. 1964). Killough is not a fourth amendment case. This fact is not considered significant for purposes of this Comment. See note 17 supra.

54 Killough made his confession during a period of illegal detention. He made a second oral confession shortly after he was arraigned but before he had obtained assistance of counsel. On his first appeal both these confessions were held inadmissible. Killough v. United States, 315 F.2d 241 (D.C. Cir. 1962).

55336 F.2d at 934. 
covery and proof of existence of the body were important to the police and thus there existed a strong incentive for them to find out from the defendant where he had buried the body. Since the fact that the mere existence of the body "in no way connected" the defendant with it was insufficient to remove the incentive for the government agents to engage in unlawful conduct to obtain knowledge of the location of the body, it would seem that such a fact should be equally insufficient to justify an exception to the exclusionary rule. With regard to the court's second rationale-that it could not conclude "that the body would not have been discovered 'but for' Killough's confession"- the comments made earlier in connection with the discussion of the Harlow and Wayne cases are equally applicable. ${ }^{56}$ In view of the artificial nature of the lines drawn, the decision can be justified only on the ground that the court did not release a murderer unpunished.

Lines have also been drawn irrationally in cases where the courtroom testimony was challenged because an illegality was used to "firm it up," 57 and in cases where because knowledge of the existence or identity of the witness was gained by the police through some unlawful conduct. In Smith $v$. United States, ${ }^{58}$ the defendant was arrested in connection with a certain robbery and placed in a lineup.

56 See text accompanying notes $49-50$ supra.

57 Judicial coin-flipping has been prevalent in cases where illegally conducted lineups involving identification of the defendant preceded courtroom testimony of witnesses, and apparently conflicting decisions have resulted. Compare Gilbert v. United States, 366 F.2d 923, 944-46 (9th Cir. 1966) (alternative holding); Carson v. United States, 332 F.2d 784 (5th Cir.), cert. denied, 379 U.S. 835 (1964) ; Payne v. United States, 294 F.2d 723, 726-27 (D.C. Cir.), cert. denied, 368 U.S. 883 (1961); Monroe v. United States, 234 F.2d 49, 56-57 (D.C. Cir.), cert. deried, 352 U.S. 873 (1956), with Wade v. United States, 358 F.2d 557 (5th Cir. 1966), vacated 87 Sup. Ct. 1926 (1967); and reith Jacobson v. United States, 356 F.2d 685' (8th Cir. 1966); People v. Stoner, 422 P.2d 585, 55 Cal. Rptr. 897 (1967) (Traynor, C.J.). Some courts believed that the use of illegally obtained evidence or an illegally obtained identification to support or make more positive courtroom testimony did not "taint" that testimony. E.g., Gilbert v. United States, supra. At least one court indicated that courtroom testimony cannot be relieved of a prior illegal "firming up." See Wade $v$. United States, supra. The intermediate position required a hearing on the issue of taint. E.g., Jacobson v. United States, supra.

The Supreme Court has recently attempted to resolve the conflict, see Gilbert v. California, 87 Sup. Ct. 1951 (1967) ; United States v. Wade, 87 Sup. Ct. 1926 (1967), articulating the following rule:

We think it follows that the proper test ... is that quoted in Wong Sun v. United States, 371 U.S. 471, 488 . . . "Whether, granting establishment of the primary illegality, the evidence to which instant objection is made has been come at by exploitation of that illegality or instead by means suffciently distinguishable to be purged of the primary taint." . . Application of this test in the present context requires consideration of various factors; for example, the prior opportunity to observe the alleged criminal act, the existence of any discrepancy between pre-lineup description and the defendant's actual description, any identification prior to lineup of another person, failure to identify the defendant on a prior occasion, and the lapse of time between the alleged act and the lineup identification. It is also relevant to consider those facts which, despite the absence of counsel, are disclosed concerning the conduct of the lineup.

Id. at $1939-40$.

68 324 F.2d 879 (D.C. Cir. 1963), cert. denied, 377 U.S. 954 (1964). 
The victim of the robbery identified other members of the lineup, but did not identify the defendant. Thus, there was no longer probable cause to hold him. Nonetheless, he was detained overnight and was placed in several lineups the next morning. As a result of these lineups, the defendant was interrogated in connection with a robbery different from that for which he had been arrested. This second robbery involved a felony-murder charge. Shortly thereafter, the defendant gave an inadmissible confession in which he mentioned the existence and first name of an eyewitness to the crime. Following up this statement the police located the witness who, after expressing some reluctance, finally agreed to testify against the defendant. At trial the defendant challenged the use of this testimony as "fruit" of his unlawful detention. The court of appeals refused to hold the testimony inadmissible. "No case has ever been cited to us in which the testimony of an eyewitness or factual witness has been excluded because his identity was discovered as a result of disclosures made by an accused during detention violative of Rule 5(a) . . . ." ${ }_{59}$ The court continued:

The fact that the name of a potential witness is disclosed to police is of no evidentiary significance, per se, since the living witness is an individual human personality whose attributes of will, perception, memory and volition interact to determine what testimony he will give. ${ }^{60}$

Shortly after Smith $v$. United States, the District of Columbia Circuit did an almost complete about-face. In Smith v. United States, ${ }^{61}$ police conducted an unlawful search of the defendant's car. In so doing they discovered a stolen transmission in the trunk. Without removing the transmission, they jotted down its serial number. The officers later obtained a search warrant; however, when they returned with the warrant the transmission was gone. Questioning the defendant, they learned that he had delivered the transmission to one Dean. Locating Dean, they learned that the transmission had been sold to Donaldson and Harvey. The police then called Donaldson's home and spoke to his father who stated that Donaldson and Harvey had purchased the transmission and would bring it to the police. Donaldson later called Harvey and told him that the transmission was stolen, but that the police did not have Harvey's name. They brought the transmission to the police. The court held that their testimony must be excluded as "fruit of the poisonous tree." The court distinguished the first Smith case on the ground that there the eyewitness

59 Id. at 881 .

60 Ibid.

61344 F.2d 545 (D.C. Cir. 1965). 
initially refused to testify and "only after reflection and the interaction of these faculties of human personality ['will, perception, memory and volition'] did [the witness] eventually relate to the jury the events of the night of the killing." 62

The combination of these two decisions has created a line in the application of the "fruits" doctrine which is based not upon the nature of the police conduct, nor upon the nature of the crime involved, but upon the vagaries and peculiarities of the individual witnesses and the promptness with which they respond to a governmental request for assistance. $^{63}$ How such a line between "tainted" and "untainted" evidence can be considered anything but "coin flipping" is difficult to perceive. ${ }^{\text {st }}$

Thus, there is considerable support for Professor Amsterdam's conclusion. However, even granting that the courts are merely "flipping" a coin, it may be argued that an individual criminal who is denied the benefit of having evidence excluded cannot claim that his rights have been violated. The exclusionary rule has only one purposeto deter unlawful police practices. This is a public purpose, not a private one. Criminals are permitted to act as "private attorney generals" only because it is necessary to the successful operation of the exclusionary rule. It is not necessary that all criminals be allowed to so act.

On the other hand, a basic tenet of our society is that all men are equal in the eyes of the law. This principle is an essential requirement of our concept of justice. Consequently, if one criminal is permitted to reap the benefits of acting as a "private attorney general," then either all criminals should be afforded a similar opportunity or the distinctions drawn between those who are and those who are not must be supported by rational and relevant considerations. The lines which courts have drawn do not meet this standard. The decisions have failed to focus on the proper issue-will exclusion serve to deter future unlawful police practices?

62 Id. at 547. (Brackets in original.)

63 See Edwards v. United States, 330 F.2d 849 (D.C. Cir. 1964) ; cf. McLindon v. United States, 329 F.2d 238, 241 (D.C. Cir. 1964). See also Note, The United States Court of Appeals for the District of Columbia Circuit: 1964-1695 [sic] Term, 54 GEO. L.J. 185, 227-28 (1965).

04 For contrary decisions holding testimony excludable where the identity of the witness is obtained through a police illegality, see People v. Albea, 2 Ill. $2 \mathrm{~d} 317$, 118 N.E.2d 277 (1955); People v. Martin, 382 Ill. 192, 46 N.E.2d 997 (1942); cf. United States v. Klapholtz, 230 F.2d 494, 498 (2d Cir.), cert. deried, 351 U.S.' 924 (1956); United States v. Goldstein, 120 F.2d 485 (2d Cir, 1941), aff'd, 316 U.S. 114 (1942). Moreover, the absence of any discussion in Wong Sun concerning the voluntariness or reluctance of Jonny Yee in turning over narcotics may cast some further doubt upon the relevance of such considerations to the issue of "taint." 
One possible alternative for the administration of the scope of taint doctrine would be to give wide discretion to the trial judge. ${ }^{65}$ He could approach each case individually, taking into consideration the quality of the local police, the need for deterrence in his particular jurisdiction and the likelihood that exclusion in the particular case would produce a deterrent effect. However, this possibility presents too great a danger that society's desire to secure convictions of the guilty is likely to produce so many exceptions to the rule as to actually destroy its effectiveness. ${ }^{66}$ Moreover, the danger of actual or apparent arbitrariness makes the suggestion impractical. ${ }^{67}$ This does not, however, require a reversion to some form of judicial coin flipping. There exist several relevant criteria which appear to be playing a part in determining where the lines of exclusion are drawn.

In Nardone v. United States, ${ }^{68} \mathrm{Mr}$. Justice Frankfurter articulated the belief that admitting only evidence obtained through a totally "independent source" (as set out in Silverthorne) might be permitting the scope of taint to spread too far. He stated that, "sophisticated argument may prove a causal connection between information obtained through illicit . . . [police practices] and the Government's proof." ${ }^{69}$ However, suggested Mr. Justice Frankfurter, "As a matter of good sense... such connection may have become so attenuated as to dissipate the taint." 70 The standard "so attenuated as to dissipate the taint" can be an extremely relevant criterion when viewed in light of the purpose for exclusion. Deterrence is the object of exclusion and only such exclusion as is likely to produce deterrence is justified. Given the Silverthorne rationale-that the deterrence is to be accomplished not by making evidence unlawfully obtained sacrosanct but simply by removing any gain ${ }^{71}$-it is possible to derive a meaningful and relevant line of "attenuation" from the Nardone test.

The purpose of depriving the government of any gain is to remove any incentive which exists toward the unlawful practice. The focus is forward ${ }^{72}$ - to prevent future violations, not punish for past ones. Consequently, where the chain between the challenged evidence and the primary illegality is long or the linkage can be shown only by "sophisticated argument," exclusion would seem inappropriate. In such a case it is highly unlikely that the police officers foresaw the

65 Nardone v. United States, 308 U.S. 338, 341 (1939): "A sensible way of dealing with such a situation ... ought to be within the reach of experienced trial judges."

66 See Amsterdam, Search, Seizure, and Section 2255: A Comment, 112 U. PA.

L. Rev. 378, 391 n.58 (1964) ; Note, 8 U.C.L.A.I. Rev. 454, 458 (1961).

67 See Amsterdam, supra note 66, at 391 n.58.

68308 U.S. 338 (1939).

69 Id. at 341 .

70 Ibid.

71 Silverthorne Lumber Co. v. United States, 251 U.S. 385, 392 (1919).

72 See Traynor, Mapp v. Ohio at Large in the Fifty States, 1962 Duke L.J. 319, 335 (1962). 
challenged evidence as a probable product of their illegality; thus it could not have been a motivating force behind it. It follows that the threat of exclusion could not possibly operate as a deterrent in that situation. Absent this, exclusion carries with it no benefit to society and should not prejudice society's case against a criminal.

A similar analysis holds true for challenged evidence which is used for some relatively insignificant or highly unusual purpose. Under these circumstances it is not likely that, at the time the primary illegality was contemplated, the police foresaw or were motivated by the potential use of the evidence and the threat of exclusion would, therefore, effect no deterrence. ${ }^{73}$

A number of cases appear to have applied such a standard. In Walder $v$. United States, ${ }^{74}$ the defendant was tried on a charge of illegal possession of narcotics. Taking the stand in his own defense, the defendant testified that he had never possessed, sold or transferred narcotics in his life. Several years earlier, in an unrelated offense, federal agents had illegally seized narcotics from the defendant. For the purpose of impeaching the defendant's credibility, the prosecution had two federal narcotics agents testify to defendant's prior possession. Despite a challenge that the testimony was "fruit" of the officer's illegal seizure, the evidence was held admissible and the Supreme Court affirmed its use for that purpose. The decision is clearly justifiable under the preceding rationale. ${ }^{75}$ The possibility of using illegally obtained information for the purpose of challenging the defendant's credibility in a trial involving a subsequent, unrelated and, at the time, uncommitted crime offers no inducement to engage in the unlawful police practice. Therefore, exclusion of the evidence will not deter future violations by police. Absent this there is no justification for excluding the evidence.

Unfortunately, the court in Walder did not utilize this reasoning. The Walder court based its decision upon an abhorrence of "letting the defendant affirmatively resort to perjurious testimony in reliance on the Government's disability to challenge his credibility." 76 This is unfortunate because it authorizes the use of illegally obtained information, not only in a subsequent and unrelated case, but also in the same case as that involving the primary illegality. The problem arose in Tate $v$. United States, ${ }^{77}$ where the defendant was arrested for robbery and, during an allegedly unlawful detention, made an inadmissible confession. At his trial, the defendant took the stand and made exculpatory statements concerning his presence at the scene of the crime and his acquaintance with an alleged confederate. In re-

73 Cf. Note, 8 U.C.L.A.L. Rev. 454, 457 (1961).

74347 U.S. 62 (1954).

75 See text accompanying notes 71-72 supra.

76347 U.S. at 65.

77283 F.2d 377 (D.C. Cir. 1960). 
buttal, the state offered the testimony of police officers to the effect that the inadmissible confession which the defendant had made was contrary to the exculpatory testimony given by the defendant. The testimony, although clearly fruit of the allegedly unlawful detention, was held admissible on the authority of $W$ alder. Here, however, the evidence was used in the same case in which the primary illegality was involved. Unlike the unforeseeability of preventing a defendant from perjuring himself in a future and unrelated crime, the prospect of preventing the defendant from testifying favorably in his defense in the present case might well provide enough temptation to provoke unlawful police conduct. Moreover, in Walder, the challenged evidence, at worst, put before the jury only evidence of a predisposition to commit the crime charged. The challenged evidence in Tate gave evidence of guilt of the crime charged, a tempting and desirable piece of evidence which should have been excluded in order to remove the incentive toward future police illegalities.

Even though the use to which the evidence obtained by the primary illegality is put is not unforeseeable, as in the Walder situation, exclusion should be refused where the illegality is of small value in producing the challenged evidence. In Warren $v$. Hawaii, ${ }^{78}$ a police officer was electrocuted by an anti-raid, device in a brothel. The device was subsequently seized by police, allegedly without proper authority. Before the trial, the device was used to refresh the memory of witnesses who testified to its existence. The testimony was challenged because of the use of the device. However, the court held the testimony properly admissible. A similar result was reached in Barkley v. United States. ${ }^{79}$ There, the defendant confessed to a murder during a period of unlawful detention. At trial he admitted the crime but claimed an insanity defense. His confession was admitted against him, but only as to the issue of his sanity at the time of the act. The admissibility of the confession for this limited purpose was sustained.

Both of these decisions are justifiable under the suggested analysis. In each case the challenged evidence was not used for its normal purpose, but for some unusual and relatively minor purpose. As such, the threat of exclusion would add little deterrence to the primary illegality and therefore should not be imposed.

Thus, from the Nardone test, at least two relevant criteria may be derived by which courts may legitimately stem the spread of "taint" and limit the number of criminals released by the "fruit of the poisonous tree" doctrine. The third and perhaps most important criterion is the offensiveness of the police conduct. ${ }^{80}$ Since the purpose of the ex-

78119 F.2d 936 (9th Cir. 1941).

79323 F.2d 804 (D.C. Cir. 1963).

so See Amsterdam, stpra note 66 , at 391 n.58; Note, 8 U.C.L.A.L. REv. 454, 455 n.10 (1961). 
clusionary rule is to deter undesirable police conduct, where that conduct is particularly offensive the deterrence ought to be greater and, therefore, the scope of exclusion broader. An application of this fact is implicit in the test adopted by the Supreme Court in Wong Sun v. United States ${ }^{81}$ _."Whether . . . the evidence . . . has been come at by exploitation of that illegality . . . ." 82 Moreover, a number of lower court decisions show a tendency to take into consideration the offensiveness of the police conduct in determining how far to extend the scope of taint.

In Parts Manufacturing Corp. v. Lynch, ${ }^{83}$ stolen goods were illegally seized by federal authorities. The defendant subsequently secured a court order for their return. However, during the period in which they were in possession, the federal officers made an itemized list and turned it over to the owners of the goods. Consequently, when they were returned to the defendant a state sheriff was waiting with a writ of replevin and immediately seized them. While the goods were stored in the sheriff's warehouse, the federal officers obtained a search warrant and seized them again. In holding that the goods constituted admissible evidence, the court found that the information used in the affidavits which supported the search warrant also had an independent source, and that the only information supporting the search warrant which was obtained solely from the original illegal search was knowledge of the present location of the goods. Concluding that that information was insufficient to compel exclusion of the goods as "fruit of the poisonous tree" the court noted:

An attempt was made to conform to the requirements of the search warrant statute. A strong prima facie case of dealing interstate in stolen articles is presented. It is too much to hold that in order to obliterate the original illegal seizure an otherwise exemplary procedure must be thrown over because the government did not close its eyes and lose track of the stolen parts. ${ }^{84}$

A similar tendency is apparent in People $v$. Gorg. ${ }^{85}$ There, narcotics seized in an unlawful search of the defendant's rented basement by police officers who were called to the scene by the defendant's landlady were held admissible, despite the fact that the landlady had no right to enter the basement nor to authorize the police to do so. In so holding the court said:

"A criminal prosecution is more than a game in which the Government may be checkmated and the game lost

81371 U.S. 471 (1963).

82 Id. at 491 . (Emphasis added.)

83129 F.2d 841 (2d Cir.), cert. denied, 317 U.S. 674 (1942).

84 Id. at 843 .

8545 Cal. $2 \mathrm{~d}$ 776, 291 P.2d 469 (1955). 
merely because its officers have not played according to the rule." . . . and when as in this case the officers have acted in good faith with the consent and at the request of a home owner in conducting a search, evidence so obtained cannot be excluded merely because the officers may have made a reasonable mistake as to the extent of the owner's authority. ${ }^{86}$

In United States $v . O^{\prime}$ Brien, ${ }^{87}$ the good faith of an officer appears again to have influenced the court. There, the defendant was arrested and charged with receiving stolen goods. A truck with the defendant's name on it had been found loaded with the stolen goods. The arresting officer asked the defendant if he had the keys to the truck. The defendant was reluctant to offer the keys, stating that he thought it might look bad for him if he were found to have them on his person. The officer told the defendant that if he gave the keys to him, he [the officer] would report that he found them on the street. The defendant gave the officer the keys. In holding that the officer could testify that the defendant had possession of the keys to the truck, the court reasoned that since the police had lawfully arrested the defendant, they could simply have searched him and found the keys. Moreover, "No right of . . . [the defendant] has been violated by this ruse of Officer McInerny who, incidentally, reported, as he promised . . . [the defendant] that he would, that he had found the keys." 88

Just as the courts appear to be favorably impressed by good police conduct, they seem equally aware of bad police conduct. In Wrightson $v$. United States, ${ }^{89}$ the defendant was illegally arrested and placed in a lineup. $\mathrm{He}$ was identified by the robbery victims and shortly thereafter confessed. In ruling the confession inadmissible as "fruit of the poisonous tree," the court said:

[T] he tendency of police officers to arrest people without warrants and without probable cause is a matter of vast public importance, and it has been of such importance since Colonial days. Courts cannot put a stamp of approval upon actions of the police when the officers, challenged by an accused, fail or refuse to demonstrate compliance with the rules which circumscribe their authority. Certainly the police have been warned enough in these respects, by the

$8645 \mathrm{Cal} .2 \mathrm{~d}$ at $783,291 \mathrm{P} .2 \mathrm{~d}$ at 473 . In terms of the substantive issue involved, reasonableness of the search without a warrant, Gorg may be overruled by Chapman v. United States, 365 U.S. 610 (1961). It is used only as an indicator of likely judicial reaction which is relevant to the purpose behind the exclusionary rule. See note 17 supra.

87174 F.2d 341 (7th Cir. 1949).

$88 \mathrm{Id}$. at 346.

89222 F.2d 556 (D.C. Cir. 1955). 
Supreme Court of the United States, by this court, and by many other courts. ${ }^{90}$

Although these several cases have articulated a sensitivity to the offensiveness of police conduct as a determinant of the proper scope of taint in each case, it would seem that there are probably many more courts which have reacted to it without giving evidence of that fact. None, however, with the possible exception of the Gorg court, has gone so far as to articulate the offensiveness of the police conduct in each case as a proper and legitimate criterion for deciding individual "fruit of the poisonous tree" issues. ${ }^{91}$ This is unfortunate, since it is one of the few criteria by which lines of exclusion can be drawn legitimately without resort to judicial coin flipping. ${ }^{92}$

90 Id. at 558. A similar statement may be found in United States v. Paroutian, 299 F.2d 486 (2d Cir. 1962). Suppressing evidence allegedly tainted by unlawful searches, the court said :

There is no showing of any reason why the few hours necessary to secure a warrant could not be spared. . . Here the only permissible inference is that the agents were careless or feared they had not amassed sufficient evidence to support issuance of a warrant. These facts demonstrate the recurrent need to suppress logically relevant evidence if acquired unlawfully, even where it may mean a criminal will go free. For in these circumstances the agents willfully or negligently ignored judicial admonitions, constantly reiterated ....

Id. at 488 .

91 However, see the concurring opinion of Chief Judge Lumbard in United States ex rel. Stovall v. Denno, 355 F.2d 731, 742 (2d Cir. 1966), aff'd, 87 Sup. Ct. 1967 (1967), where he states: "I am particularly unwilling to exclude all identification in this case because Mrs. Behrendt's testimony seems reliable and because alleged police improprieties were unintentional and technical." (Emphasis added.)

92 "What should be of primary concern [of the exclusionary rule] is . . . the grievousness of official lawlessness." Traynor, Mapp v. Ohio at Large in the Fifty States, 1962 Duke L.J. 319, 335 (1962).

The cases also disclose a tendency by the courts to react to a fourth criterionthe offensiveness of the crime involved. Judge Berger expressed abhorrence at extending the exclusionary rule to free a murderer in Killough v. United States, 315 F.2d 241, 259 (D.C. Cir. 1962) (dissenting opinion). "It is shocking to me that upon such tortured grounds the court reverses the conviction of this man who has confessed to a bizarre and brutal murder." Id. at 265. (Miller, J., dissenting). "[W]here either the offense or the illegal procedure involved is minor, the decisions seem to have been influenced by that factor." Note, 8 U.C.L.A.L. REv. 454, 455 n.10 (1961). Prior to Mapp, a Maryland statute excluded evidence discovered by unlawful searches in misdemeanor cases, but not in felonies. Hall v. Warden, 313 F.2d 483, 490 (4th Cir.), cert. denied, 374 U.S. 809 (1963). This is an admittedly relevant criterion considering the tension between the need for deterrence and the desire to incarcerate criminals; however, it seems unadministrable under the present state of knowledge. When the crime is most offensive is when this criterion would call for admission, and yet it is when the crime is most offensive that police are most likely to violate rights in an attempt to apprehend the criminal and, consequently, the time when deterrence and, therefore, exclusion are most needed. Since the necessary knowledge to reconcile these competing interests in any particular case is not yet available, this criterion is not yet useable. 